\title{
Universiteit
}

Leiden

The Netherlands

\section{The charmed circle: mobility, identity and memory around Mount Mayon (Philippines) and Gunung Awu (Indonesia) volcanoes}

Bankoff, G.; Newhall, C.; Schrikker, A.F.

\section{Citation}

Bankoff, G., Newhall, C., \& Schrikker, A. F. (2021). The charmed circle: mobility, identity and memory around Mount Mayon (Philippines) and Gunung Awu (Indonesia) volcanoes. Human Ecology, 49(2), 147-158. doi:10.1007/s10745-021-00225-0

Version:

Publisher's Version

License:

Licensed under Article 25fa Copyright Act/Law (Amendment Taverne)

Downloaded from: https://hdl.handle.net/1887/3201633

Note: To cite this publication please use the final published version (if applicable). 


\title{
The Charmed Circle: Mobility, Identity and Memory around Mount Mayon (Philippines) and Gunung Awu (Indonesia) Volcanoes
}

\author{
Greg Bankoff ${ }^{1}$ (D) Chris Newhall $^{2} \cdot$ Alicia Schrikker $^{3}$ \\ Accepted: 18 February 2021 / Published online: 11 March 2021 \\ (C) The Author(s), under exclusive licence to Springer Science+Business Media, LLC part of Springer Nature 2021
}

\begin{abstract}
Volcanoes are surrounded by villages, towns, and polities that are constantly shifting location to benefit from the rich soils generated in the aftermath of eruptions, while, at the same time, avoiding the worst of their destructive potential. We explore the attraction of volcanoes in a Southeast Asian context through a comparative examination of the communities surrounding Mount Mayon in the Bicol peninsula of the Philippines and Gunung Awu on the island of Sangihe Besar in Indonesia. These volcanoes influence the location of settlements, forms of community identity, and the expression of cultural memories. We argue that risk awareness programmes that disregard the extent to which a volcano is embedded within the physical and mental fabric of a society and fail to connect to local historical cultural memory are likely to have little lasting effect on reducing people's vulnerability.
\end{abstract}

Keywords Social volcanology $\cdot$ Adaptation $\cdot$ Identity $\cdot$ Memory $\cdot$ Mount Mayon $\cdot$ Philippines $\cdot$ Gunung Awu $\cdot$ Sangihe Besar island $\cdot$ Indonesia $\cdot$ Southeast Asia

\section{Introduction}

Volcanoes that erupt on a regular basis shape the landscapes and the histories of the people who live around them. These settlements are constantly shifting location to benefit most from the rich soils generated in the aftermath of eruptions, while, at the same time, avoiding the worst of their destructive potential. Volcanic soils cover less than $1 \%$ of the world's land surface and support $10 \%$ of the world's population but they are dangerous places to live (Neall 2009). ${ }^{1}$ Thus there are concentric bands of settlement around a volcano: too close, a community risks being seared by its heat; too distant, it does not benefit from the fertility of its soils. In between is a zone where the earth is fertile and the inhabitants prosper, although

\footnotetext{
${ }^{1}$ Since 1900 , nearly 5 million people have been affected by volcanic events and over 91,000 people have died (Doocy et al. 2013). At a minimum, more than 500 million people currently live within the potential exposure range of the $550+$ active volcanoes that have erupted within the last 10,000 years (Small and Naumann 2001).
}

Greg Bankoff

gbankoff@ateneo.edu

1 Ateneo de Manila University, Quezon City, Philippines

2 Mirisbiris Garden and Nature Center, USGS (retired), Santo Domingo, Albay, Philippines

3 Leiden University, Leiden, Netherlands there is always the need to maintain a fine balance between profit and risk, permanence and flight.

Tambiah (2013) uses the term 'galactic polities' to describe the structure and operation of precolonial kingdoms in Southeast Asia. Each of these polities he compares to a centre-orientated universe or mandala exercising ever diminishing sway over its satellite bodies the further they recede from the central point. In the mandala model, this central point is a volcano, Mount Meru, the sacred mountain of Hindu, Jain, and Buddhist cosmologies. The mountain is not only the physical centre of the universe but is also its metaphysical and spiritual centre. In Javanese myth Mount Meru is represented by Mount Semeru (Great Mountain), the tallest mountain on Java (Mabbett 1983).

The sacred as well as the physical presence of volcanoes exert a centripetal attraction on communities around them. Settlements coalesce and disperse as locations are selected, settled or resettled, and abandoned. Volcanoes are also integrated into local identity-making, creating linguistic and political islands in the past with their individual characteristics, the 'little tradition' of the village or the local polity (Redford 1956). Eruptions become absorbed by local communities both as cultural memory expressed in rituals or stories, and as experience-based memory passed between generations. Within the 'charmed circle' of the volcano, community and landscape are shaped by the 'mutuality' of humanenvironmental interactions (Hoffman and Oliver-Smith 1999: 6). Both history and terrain can be read as products of 
this interaction: where people live, what they do, and how they think, on the one hand; and how human activities, practices, and beliefs affect the course (although not the timing) of eruptions, on the other. Over the centuries, society and environment adapt to one another to create 'co-volcanic societies' (Bankoff 2020).

We explore the attraction of volcanoes in a Southeast Asian context through a comparative examination of the communities surrounding Mount Mayon in the Bicol peninsula of the Philippines, and Gunung Awu on the island of Sangihe Besar in Indonesia. We adopt a social volcanology approach to how these volcanoes become an integral part of people's lives affecting where they live, what they think, and how they make sense of their pasts. Social volcanology calls for an examination of local societies to better understand the nature of volcanic risk (Donovan 2010). After an initial discussion of the physical features of each volcano and the characteristics of their eruptions, we compare these respective histories to show how they have affected local patterns of settlement, forms of community identity, and their myths, rituals, and ceremonies to reveal both the centripetal forces that draw people towards a volcanic centre, and the centrifugal forces that drive them away. It is this measure of the volcano's power to attract and repel that ultimately determines levels of community risk.

\section{The Volcanoes}

Mount Mayon is a perfect cone rising $2462 \mathrm{~m}$ above the Albay Gulf, with a crater just 150-200 $\mathrm{m}$ in diameter and with no deep valleys at present. In contrast, Gunung Awu is broad and squat, rising to just $1318 \mathrm{~m}$ above sea level, has a caldera of at least $1.5 \mathrm{~km}$ in diameter, and has flanks split by several deep valleys (Kemmerling 1923: 7-9, 12-14). Within this caldera lakes sometimes form, though these were temporarily displaced by the last eruption in 2004. The very existence of a caldera at Awu, however, suggests at least one large eruption in the prehistoric past, just a bit smaller than that of Pinatubo in 1991 (Newhall and Punongbayan 1996).

Both volcanoes produce a mix of explosive and effusive eruptions. The largest historical explosive eruption of both volcanoes is a moderate Volcanic Explosivity Index (VEI) 4, comparable to the 2010 eruption of Merapi (Surono et al. 2012). Both produce crystal-rich basaltic andesite magma with $\mathrm{SiO}_{2}$ content between 49 and 57 (Newhall 1979; PVMBG 2011: 380-94). Historically, too, both have produced bomb-rich pyroclastic flows that, together with lake-induced lahars (destructive mudflows), constitute the primary hazards for nearby communities. Also, both volcanoes have produced phreatic explosions in between magmatic eruptions, more and larger at Awu than at Mayon because of the former's caldera and crater lake. When lavas are extruded non-explosively onto the caldera floor of Awu, they mound up to form lava domes. Similar or slightly less viscous lavas at Mayon exit the small crater immediately and move onto the steep upper slopes, from which they continue downslope as lava flows or pyroclastic flows, the latter occasionally reaching the sea.

Comparing the fatalities that both volcanoes' eruptions have exacted historically from local communities, at Awu, VEI 4 eruptions in 1812 and 1966, and VEI 3 eruptions in 1711, 1856, and 1892 (all with pyroclastic flows and lahars) have killed more than 8000 people. At Mayon, VEI 4 eruptions in 1814 and 1897, and VEI 3 eruptions in 1766, 1834, 1845-46, 1853, 1871-72, 1881, 1886, 1928, 1968, 1984, and 2001 have killed approximately 2000 persons in total. The reason for the higher death toll around Awu may be the smaller land area on Sangihe Island and the short distance between cone and coast that forces people to live in closer proximity to the volcano than communities around Mayon, which is situated on a peninsula that allows population centres to disperse more widely. ${ }^{2}$ It is possible the higher death toll may also relate to the relative greater frequency of Mayon's eruptions compared to Awu's that affords locals a keener appreciation of the dangers of living in proximity to an active volcano.

Mayon almost always has a visible gas plume and, in typical inter-eruptive periods, the volcano releases roughly $500 \mathrm{t}$ of $\mathrm{SO}_{2}$ /day (Bouvet de la Maisonneuve et al. 2018). In the days prior to eruptions at Mayon, $\mathrm{SO}_{2}$ emission can increase severalfold due to a modified form of convection of magma in the conduit, with gas-rich magma rising continuously at rates of a few $\mathrm{cm} / \mathrm{s}$. When it nears the surface, gas that can no longer stay dissolved forms a magma foam like the head on a glass of beer. The foam is permeable, so gas leaks out to the atmosphere (i.e., in the visible plume) and the degassed foam collapses into nearly solid droplets or blebs of rock that sink down into a crystal graveyard beneath the volcano (Shinohara et al. 2003). This continuous convection and outgassing process is called 'open-conduit' behaviour because magma in the conduit rarely if ever solidifies between eruptions. In contrast, Awu has no visible, continuous plume. There might be some continuous degassing, but not as much as at Mayon, and what there is may be getting absorbed or scrubbed into the groundwater system. Thus, Awu seems to exhibit 'semi-plugged conduit' behaviour, with magma in the conduit partly solidifying between eruptions. Why Mayon can maintain steady-state openconduit convection while Awu cannot is still unresolved, but one possible explanation is that the rate of magma re-supply

\footnotetext{
2 The island of Sangihe Besar is shaped in a figure-eight with Gunung Awu at the centre of the northern 'circle'. The island is approximately $45 \mathrm{~km}$ in length and has a diameter of $15 \mathrm{~km}$ at its widest. Recent publications suggest a higher overall casualty figure for Awu of 11,048 persons on the assumption there was an eruption in 1822 causing around 3000 fatalities (Christian et al. 2020: 19). The Dutch official A.J. van Delden who visited the island in 1825, however, makes no mention of an eruption in 1822 (Delden 1825).
} 
beneath Awu is slightly lower than that beneath Mayon. Awu is thought to be older and less vigorous than Mayon.

This difference between open- and semi-plugged conduits is significant as it leads to important differences in the strength of eruption precursors and in the frequency and sizes of eruptions. When magma in a conduit partially or wholly solidifies, fresh resupply from deep within the volcano needs to break through choke points before it can erupt. The choke points allow pressurization of magma, which leads to relatively strong seismicity and easily measurable inflation (swelling) of the volcano (Whelley et al. 2015). Conversely, when magma in conduits does not solidify, as in Mayon, there is always magma close to the surface and fresh resupply needs only a little pressure to move up the conduit. Seismicity and deformation are subtle (sometimes unnoticeable), and might occur months before eruption, and therefore provide no warnings. The most reliable short-term precursor at Mayon is usually an increase in $\mathrm{SO}_{2}$ gas, with or without accompanying seismicity and deformation. The final push to eruption (with warnings) might be as short as hours to days. So, in terms of short-term warning purposes, Awu is more predictable than Mayon.

The other consequence of differences in convection vs. plugging is that eruptions from a plugged or semi-plugged volcano will be less frequent than at an open-conduit volcano. One can see the difference in average repose period $(\sim 16$ year at Awu vs. 4-5 years at Mayon), and the difference becomes even more pronounced if one treats phreatic explosions as precursory unrest rather than as eruptions per se (average magmatic repose $\sim 24$ year at Awu and $\sim 6$ years at Mayon). At plugged volcanoes, there is a correlation between the sizes of eruptions and the length of repose, as the length of repose corresponds to the time available for gases to accumulate. At semi-plugged volcanoes, the relationship is more tentative and the period of repose before the largest documented explosive eruptions of Awu (1812 and 1966) were several decades to a century long. At open-conduit volcanoes like Mayon, on the other hand, the size of eruptions bears no relation to prior repose. In this case, explosive magnitude is determined mainly by the volume of fresh magma resupply, which may relate more to regional earthquakes than to repose. Even at Awu, relatively large influxes of fresh magma might control the biggest eruptions, but this hypothesis remains to be tested.

An important control on human interaction with Mayon is groundwater. The upper slopes of Mayon serve as a catchment but springs generally do not occur above $\sim 100 \mathrm{~m}$ elevation ( $\sim 8 \mathrm{~km}$ from the summit), which sharply limits the upslope expansion of settlements. Water tables at the sensitive $8-\mathrm{km}$ radius also drop in response to fresh magma intrusion at depth (owing to volumetric dilatation or stretching) and then rise again as magma rises into the cone and nears eruption (volumetric compression). Elders around Mayon know that if water wells at $8 \mathrm{~km}$ distance dry up during the rainy season, the volcano is preparing to erupt once again (Newhall et al. 2001). We have not found comparable information from Awu, though it can be inferred that farms at 2-km distance from the crater must have access to a year-round source of fresh water.

Populations within $10 \mathrm{~km}$ of the summit are $\sim 250,000$ at Mayon and 26,000 at Awu. However, the nearest villages at Mayon are $6 \mathrm{~km}$ from the summit, while those at Awu are at just $2-3 \mathrm{~km}$. During eruptions, as many as $50,000-70,000$ residents typically require evacuation around Mayon and the percentage of the population can be even higher at Awu - in 2004 totalling $\sim 17,000$ people $(65 \%)$. At Mayon, evacuated villagers can generally move straight downslope, and there is the potential to increase or decrease radii of evacuations gradually as volcanic activity fluctuates, out to a normal maximum of $8 \mathrm{~km}$. The largest historical eruptions of Mayon, 1814 and 1897 , have sent pyroclastic flows and surges to distances of $11 \mathrm{~km}$ and $10 \mathrm{~km}$ from the summit, respectively, so that evacuation plans are insufficient for the worst-case scenarios. At $\mathrm{Awu}$, distances to the coast on the west, north, and east are much shorter, and within striking range of pyroclastic flows, so evacuations must be nearly complete, except in the south where there is sufficient land to receive evacuees.

Thus, Mayon and Awu, 'stars' of similar magnitude, share certain characteristics but they also differ in important respects that have implications for the location of settlements and the movement of peoples. They dictate where people live and for how long, and also how they think about themselves, giving rise to local identities forged by the particularities of eruptions and their aftermaths as reflected in place names, vernaculars, and even the formation of political units. People have learned what it means to live with the uncertainty of sudden death, to normalise risk by telling stories that pass on knowledge about past eruptions, and through enacting rituals and ceremonies to both appease the volcano and instil a sense of safety and security. There is as much a need, therefore, to reveal the social characteristics of a volcano as there is to understand its physical properties.

\section{Methodology}

As part of a social volcanology approach to this research, we enlisted an interdisciplinary team including a volcanologist as well as historians versed in both archival work and social science practice. Archival research in national and regional repositories in the Philippines and Indonesia provided hard to find data on eruptive sequences and local settlement patterns, particularly the relocation of towns and villages or the shifting boundaries of local polities. Historical search was supported by 10 formal and informal interviews (five around Mayon and five around Awu) with residents living in proximity to 
the volcanoes, including local historians and government officials. These interviews provided material on more recent eruptions and the customary practices and religious beliefs associated with them in addition to invaluable insights on the origins of place names. A particular feature of the interdisciplinary methodology we employed was the transect interview conducted while walking through a volcanic landscape with a knowledgeable resource person who pointed out significant features of the local terrain while relating stories associated with the site.

\section{Mayon}

The Bicol peninsular has long been an area of human settlement attracted by the rich volcanic soils and intensive agriculture. Mayon is only the most prominent of the volcanoes that stretch in an arc from Mount Labo in Camarines Norte to the Gate Mountains in Matnog, Sorsogon. The southernmost tip of this chain is marked by Bulusan, the only other currently active volcano in the region. There is evidence of precolonial polities in the Ibálong, the regional folk epic, and the region was incorporated early into the colonial state as a centre of Spanish power in 1574 (Espinas c1996). Mayon, by far the most active of these volcanoes, has nevertheless exerted the primary centripetal attraction for local communities, profoundly influencing the spatial pattern of human settlements and accounting for their frequent relocation and abandonment. At the same time, the volcano and especially the nature of eruptions has conferred a sense of local and even linguistic identity on surrounding peoples, while the aftermath of such events and personal experiences have been memorialised in myths, rituals, and ceremonies that also serve to normalise the risk of living so close to the volcano. ${ }^{3}$

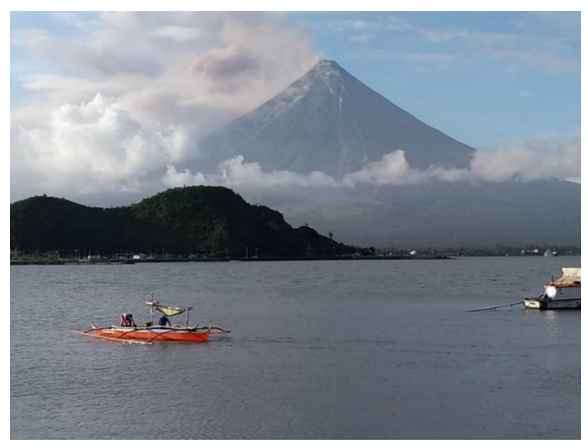

Daragang Magayón (the Beautiful Lady) in eruption January 2018 (Photo by the authors)

\section{Patterns of Human Settlement}

Rich volcanic soils or andisols have long attracted human settlements whose residents have traded the risk of an eruption

\footnotetext{
${ }^{3}$ The sense of identity represented by Mayon has even taken on national form in that the volcano is depicted on the reverse side of the current $\$ 100$ note.
}

against the advantage of higher agricultural yields. Around Mayon, settlement site has always been a fine balance between risks, especially given the frequency of eruptions that keeps the memory of danger fresh: near enough to the volcano to benefit from its soils, no closer than the sources of freshwater, and preferably on the lee side of prevailing winds. If soil fertility, freshwater availability, and seasonal wind directions have not varied drastically over recent centuries, the nature of Mayon's eruptions have.

Successive eruptions have changed the contours of the volcano's rim, as first one side of the cone and then another crumbled before being reconstituted. Towns considered relatively safe when initially settled later proved to be in the direct path of oncoming lava and lahars as the height of the cone's sides varied or the channels running down the sides filled and flows shifted. José Coronas (1898:18) noted just such developments in his treatise on the 1897 eruption of Mayon, observing how the route that lava took alternated over the years. Beginning with a description of the 1814 eruption, he describes how lava destroyed the towns of Cagsawa, Camalig, and Budiao, all situated on the southern side of the volcano. Lava flows continued to the south and southeast in the ensuing eruptions of $1871,1881,1885,1886$, and 1887. However, this last eruption altered the respective heights of the cone's rim so that, in the subsequent eruption of 1890, lava flowed down the eastern flank towards the southwest. The town of Libog, long considered safer, was thus placed in imminent peril.

The inhabitants of the region's major trading centre of Cagsawa, apprehensive of lahars, petitioned the provincial governor to transfer to a new site at Daraga in 1771 (Mallari 1986). Sadly, this relocation was still unrealised before the major eruption of 1 February 1814. Eye-witness accounts give a harrowing description of the loss of possibly 1200 residents in this event, although this figure is likely inflated. ${ }^{4}$ Cagsawa along with Camalig and Budiao were destroyed and two other towns, Guinobatan and Albay (now Legazpi City), the provincial capital, were seriously damaged although the public buildings survived in both cases. The opening of a new vent on Mayon's flank proved particularly fatal to the town of Budiao, burying it beneath a mantle of volcanic ashes and pyroclastic materials. Two hundred people alone perished in the town's church where they had sought safety (AOM 1814: $20 \mathrm{ff}$ ). Many communities in the eruption's aftermath sought to relocate to less vulnerable sites.

The governor of Camarines subsequently wrote to the governor-general in Manila to suggest that the five ruined towns and the three surviving ones be relocated to more secure locations (ibid.). Survivors from the devastated towns of Budiao and Cagsawa were combined into one settlement at a new site, Daraga, much along the lines originally proposed

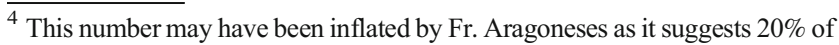
the local population died in the eruption (Aragoneses 1815).
} 
in 1771. Many locals evidently did not wait for official sanction and simply moved. One example of how settlements orbited around Mayon is the history of Camalig. In the aftermath of the eruption, residents first transferred the town's civil and religious administration to Tundol, the legendary centre cited in the Ibálong. This site was soon rejected for another location at a higher elevation at what is now Barangay Palanog. For whatever reasons, this position also was considered unsatisfactory and the community next settled in an area 'way up in the uplands' at Quilaponte, but this was too far away from the residents' irrigated fields. After two years, the community moved to a new settlement at Barangay Baligang, only a few kilometres distant from the town's original site. A church was constructed but soon afterwards burnt down along with many of the surrounding houses, and the inhabitants finally petitioned the authorities to return to their original location at Camalig. On this occasion, the new settlement was not altogether abandoned and Barangay Baligang is now known as Camalig Nuevo (New) to distinguish it from the original site at Camalig Viejo (Old) (Local Historian 2018, January 17). To help them rebuild the town, the inhabitants were granted relief from tribute and taxation for the next seven years (AOM 1814: 25-28).

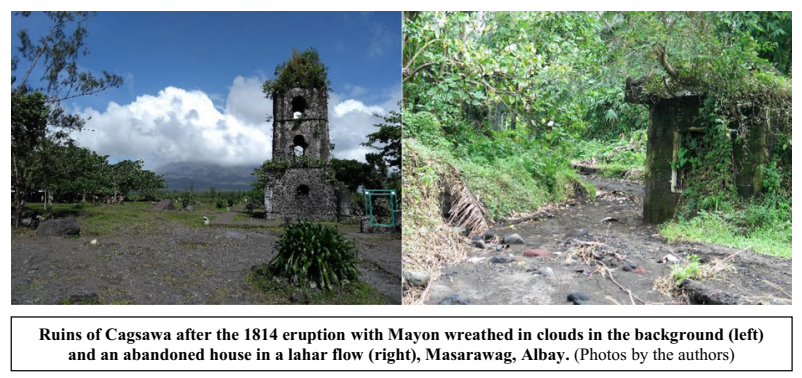

New sites were settled and abandoned for a variety of reasons. In the case of Camalig, each resettlement proved unsatisfactory either because farmers still needed access to their fields or because 'people did not feel comfortable' and 'were apprehensive that another 1814-kind of disaster might occur' (Local Historian 2018, January 17). Mayon, however, was not the only risk people faced. While the Bikol region is not an island like Sangihe Besar where Awu is located, it is a peninsular and the sea is never far away. Fr Francisco Turbino, the parish priest of Guinobatan, another town seriously affected in 1814 , lamented how in the space of $5 \frac{1}{2}$ hours 'the work of countless years of sweat and toil by their ancestors had been lost' (AOM 1814: 38ff). Its inhabitants decided to relocate to a coastal site at Panganiran Bay. Unfortunately, this new location exposed the community to raids by Moro pirates who remained a scourge in the region until the mid-nineteenth century (Warren 1981). The ferocity of these raids soon forced the residents to retire from the coast further inland to Barangay Mauraro before finally resettling once again at the original site of Guinobatan (Local Historian 2018, January 17). In this case, the threat from the sea defined the limits to the gravitational pull of the volcano.

\section{Local Identities}

The extreme example of 1814 vividly illustrates how the volcano exerted an influence over the location of settlements, attracting people to establish them and then influencing their relocation to alternative sites as the eruptions' profile changed. Many settlements were in constant flux until well into the twentieth century. And just as the volcano exerted sway on settlement patterns, its eruptions also fostered forms of local identity among the surrounding population. Place names are one way in which people found identity in an environment often characterised by volcanic activity. A sense of identity, too, was conferred by the radial flows of rainwater and lahar down the flanks of the cone, dividing lowland areas into discrete 'islands' sometimes marked by linguistic differences.

Many local places reflect the mass conversion of indigenous peoples to Catholicism and have names such as San Rafael, San Roque, or Salvacion. The names of other settlements describe topographical features of the surrounding landscape, such as Bubulusan signifying running water. Others are named after local flora like Bagacay, a weed-like bamboo, and Bonga, a kind of palm tree. Still others, however, have a much more direct associated with the volcano. A name shared by one of the surrounding villages and several neighbourhoods in local towns is Binanwaan, literally 'a town that was abandoned and has been restored.' The name suggests a site that was first abandoned but to which the population subsequently returned. While the destruction and abandonment of Cagsawa and its relocation to Daraga may be the best-known example of this relocation pattern, not least because the original site has now been developed as a tourist attraction, many of the towns and villages around Mayon share similar historical narratives (Mallari 1986). The names of many settlements reflect a direct or indirect association with the volcano: Binogsocan or a location onto which something fell, Basud or the debris left after lahar, Magapo or a rockstrewn area, Uson or a place of pyroclastic flows, and Bantayan or a place from which to keep watch (Local Historian 2018, January 17).

The volcano has also had a deeper cultural impact than determining the site of settlements or how they are named, and has shaped how people communicate. The origin and endurance of the many distinct dialects and languages spoken around Mayon is attributable to the relative topographical isolation imposed by the volcano. In the past, the rivers, mountains, and forests posed barriers to communication and trade, hindering movement between communities. The volcano's dominating height imposes a radial pattern, with the crater at its centre, in which rainwater or flash floods down its slopes divide the surrounding landscape into discrete cultural micro- 
regions. The relative isolation thus imposed encouraged linguistic divergence and the creation or, at least, retention of separate languages (O’Brien 1968). Thus, Camalig, Daraga, Guinobatan, and Villar spoke East Miraya or Albay Bikol (Albayanon), one of three languages that compose Inland Bikol. The residents of these towns still speak distinct dialects. Other centres, such as the lake town of Buhi (though outside the immediate vicinity of the volcano) retained distinctive languages relatively unadulterated by Spanish and local influences. The town's remote location ensured its separate linguistic development (Local Historian 2018, January 17). Only with the advent of the railroad and the motorcar in the early twentieth century have these barriers disappeared, although the distinctive sense of local identity remains a notable feature of the region.

\section{Myths, Rituals, and Ceremonies}

The aftermath of eruptions also lingers long after all physical traces of the event are lost or absorbed into the surrounding topography. Memory of past eruptions are immortalised in local myths, rituals, and ceremonies partly designed to preserve the historical experience but partly, too, to assuage the volcano. These cultural memories are passed down through the generations in the form of invocations and stories about the origins of the volcano and what must be done to prevent another catastrophe.

Supposedly Mayon is the abode of Gugurang, the Bikolano god of light and fire, and chief arbiter between right and wrong. Loud moaning of the earth and the rivers of fire running down its flanks were traditionally seen as signs of the volcano's displeasure at wrongful acts. While there is little evidence that locals still link the volcano with a preHispanic deity, the association of Mayon with the legend of Daragang Magayon remains a well-known and popular tale. In this narrative, the volcano is depicted as a beautiful noble maiden who stabs herself to death over the fallen body of her lover (Espinas c1996: 115-17). When the clouds shroud the volcano's cone, which they frequently do, the couple are said to be lovemaking. This type of sexual allusion in which eruptions especially are associated with the male ejaculation are not unique to Mayon and may have their genesis in the subsequent fertility of volcanic soils (Schlehe 1996: 396, 405).

The beautiful but brooding presence of the mountain, visible for great distances on all sides, was also historically thought to be the abode of the dead. Bodies carried up its slopes were said to be reincarnated in its 'fires.' The spirits of the dead are similarly believed to inhabit the slopes of Mount Merapi on Java, indicating a more widespread system of beliefs associated with volcanoes (Schlehe 1996: 395). This practice so alarmed early Spanish missionaries that two Franciscan monks ascended the volcano in 1592 to disabuse the locals of their pagan superstitions: one never returned and the other is said to have died in that same year (Jagor 1875: 93). Mayon remained a site of religious veneration even after the conversion of local people to Christianity. Post-conquest practices, however, were focused more on protecting communities from the volcano. In Bunga, for instance, locals believe that an ermitanyo, a holy figure, will miraculously show himself to warn locals of an impending eruption. His presence can be discerned from the footprints' preserved in the solidified lava flow left behind from his climb up the mountain to intercede with God.

Sometimes, too, local people play a more direct role in their own salvation. Perdón is a religious practice in which mainly women process through their villages over seven nights to ward off evil spirits and any danger from the volcano. These processions are precautionary measures in which celebrants alternately sing and pray. They are organised by the hermana mayor or the primary representative of the Catholic Church in the community and follow routes that transverse the settlement's main thoroughfares, traditionally always passing through or terminating at the cemetery. The emphasis on the dead, perhaps, provides a link with pre-Christian belief systems. The name perdón derives from the Spanish word meaning forgiveness. The association of the volcano with God's displeasure and of an eruption with divine punishment remains a persistent motif in popular imagination. One elderly woman, speaking of her childhood in the 1930s, remembered being awakened at four in the morning to sing 'a song addressed to God to forgive us of our sins,' and added that 'people really believed at the time that it [a volcanic eruption] was a punishment of God' (Local Resident 2018, January 20). The processions she describes were penitential in nature with participants walking barefoot.

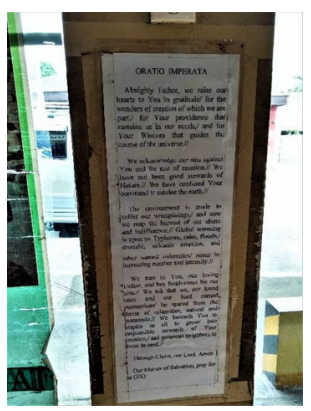

Oratio Imperata prayer inside a local shop around Mayon, Camalig, Albay. (Photo by the authors)

Such sentiments may not differ greatly today. The Oratio Imperata, the obligatory prayer for the deliverance from calamities, is very evident in public venues around Mayon. Part of its third stanza reads:

Global warming is upon us, typhoons, floods, volcanic eruptions

and natural calamities occur in increasing number and intensity. 
We turn to you, our loving Father, and beg forgiveness for our sins.

Guilt, ritual, ceremony, and forgiveness are ways in which the volcano has been memorialised in popular imagination, conferring upon 'Mayon's people' a badge of identity and an inclusiveness of community. It is also an astute method that local inhabitants have adopted to help normalise the risk the volcano poses to their daily lives.

\section{Gunung $\mathrm{Awu}^{5}$}

The Sangihe archipelago, of which Sangihe Besar is the main island, borders waters of the Philippines south of Mindanao and is part of the Indonesian province of Sulawesi Utara (north Sulawesi). The Austronesian population of the island maintained political and commercial ties with Mindanao and with Ternate in Maluku in the past. Only in the late colonial times did the orientation of the political rulers get redirected to Manado, the colonial administrative centre of the region (Lopez 2018: 134-152). The Sangirese take pride in tracing their royal lineages back to Maka-Ampo, the powerful and ruthless king who is said to have once united the island. According to the Bekem Makaampo ('story of Maka Ampo') the king held a seat on top of Gunung Awu and his grandmother was princess Din, one of the spirits who lived in the nearby volcano Ruang (Aebersold 1957). In the Sangihe archipelago, volcanoes are integrated into regional cosmology and can also be understood as political or historic actors. In purely volcanological terms, Awu's history differs considerably from Mayon, with its shallow peak and broad old crater, although its relatively recent history of human interaction bears remarkable similarities.

\section{Patterns of Settlement}

The history of settlement and relocation around Awu relates directly to the local nature of political power. More than land, people formed the base of power in Sangihe, and an eruption of Awu simultaneously posed a challenge as well as an opportunity for political power. Like Mayon, Awu attracted human settlement because of its fertile soils. Settlement occurred near the coast along the rivers that ran down the mountain. Even prior to the sixteenth century, coconut gardens were cultivated for copra production, stimulated by contacts with the Philippines, while Arab and Chinese traders also found their way to the island. Livelihoods were centred mainly on

\footnotetext{
${ }^{5}$ Fieldwork for the research on Awu was carried out with the aid of Dr. Ariel Lopez from the University of the Philippines Diliman, Nono Stevano Agustinus Sumampouw from Universitas Sam Ratulangi, Manado, and Hendra Birahm from Naha.
}

fishing and sago and coconut cultivation, leading to early deforestation of the area around the volcano. Interaction with Muslim traders led some islanders to convert to Islam. Others converted to Catholicism with the arrival of the Spanish in the sixteenth century, and to Protestantism when the Dutch made Tabucan an outpost of its VOC (Dutch East India Company) empire in the seventeenth century. However, ancestor worship remained a central element of local spiritual life (Henley 2005: 65-71; Lopez 2018: 14-18, 134-51).

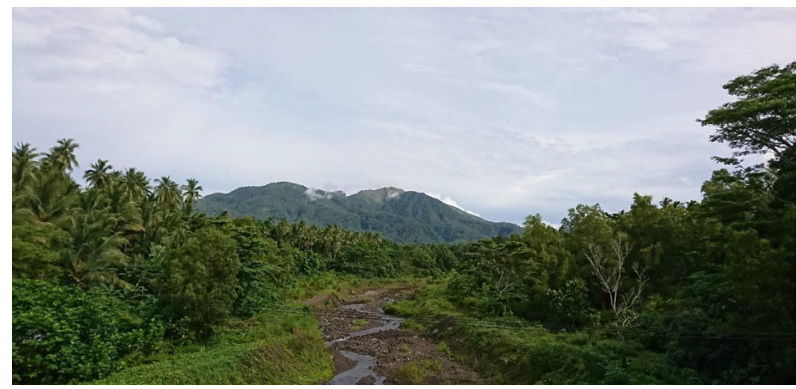

A view of Gunung Awu from Kolongan, January 2018. (Photo by the authors)

At the end of the seventeenth century, authority in the northern part of the island, essentially the area around Awu, was divided among three polities: Tabucan in the east, Kendahe in the north, and Tahuna in the west. Tabucan and Kendahe also claimed authority over the southern polities of Salurang and Ngalipaeng and exerted influence beyond the island. Kendahe, for example, maintained connections in Sarangani, Mindanao. South from Tahuna, further away from the volcano, were the polities of Manganitu and Tamako (Lopez 2018: 134-51). A seventeenth century visitor noted that each village on the shore backed against a hill or mountain that offered a refuge in case of violent attacks or calamities (Leupe 1867: 255-56).

The three polities around Awu and their subject villages were mainly located along the coastal strip with gardens on the volcano's slopes. Upland areas were also used for livestock. By the late seventeenth century the Dutch considered the Sangihe islands as in their sphere of influence, which they reaffirmed through contracts with the rajas of the different polities and by encouraging them to convert to Protestantism. Actual Dutch presence remained limited until the midnineteenth century, when the island was assigned a controleur (government official). In the same period, a new and active generation of missionaries arrived and (steam) shipping in the region expanded. In comparison to Mayon, full-blown colonialism came late to the island (Lopez 2018: 134-82). At present the administrative division of the island still follows the boundaries of these polities, which suggests strong continuity in settlement location and land usage. Yet the frequent eruptions of Gunung Awu not only caused death but also forced many islanders to move both around the island and away from it. 


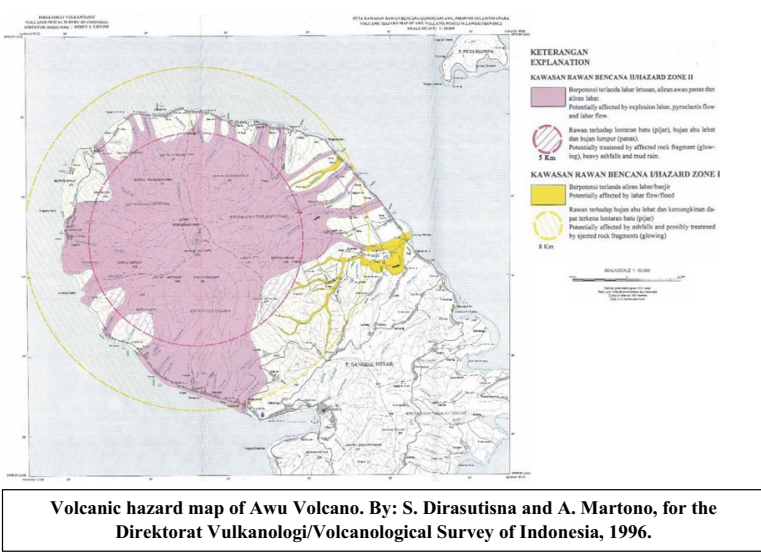

As with settlements around Mayon, the threat of deadly eruptions often caused only temporary abandonment. Kolongan, a region between Kendahe and Tahuna, was destroyed during a seventeenth century eruption, causing Kolongan to come under the authority of the raja of Tahuna, which strengthened his power relative to the others (Kutoyo and Sigarlaki 1982: 47). After the major eruption of 1856, the raja of Tahuna became anxious about the movement of his people to other regions, while the raja of Tamako, a small polity to the south, was eager to allow 250 refugees from Tahuna-Kolongan to settle on his land (Riedel 1867: 91-96; Schrikker 2016: 225-254). Awu eruptions could influence the balance of power directly.

Still, at least since the late seventeenth century, the polities as political centres survived repeated disasters despite the constant movement of their subjects. Sometimes the political centres themselves had to relocate in the aftermath of the eruptions to secure continuity. In 1711, the palace of Kendahe, located near the river Maselihe, was destroyed and rebuilt further north, away from the river, in an area better protected against lahars by hills. After severe damage in 1892 (ANRI 1892), the centre of Tabucan also relocated to the next eastern bay. In both cases, the moves entailed trading ease of access to the sea for better protection against the volcano. This historic relocation of settlement is reflected in the widespread use of the adjectives lama (old) and baru (new) with place names. ${ }^{6}$ The villagers of Tariang on the volcano's northeastern slopes relocated to the south, further away from the cone, though the new community continued to maintain ties with those who remained at the old site (Darenoh 2012). This pattern of resettlement shows both an awareness of safer zones and an attempt to limit risk. Moving away from one risk, however, often exposed people to other kinds of danger. As late as 1920, girls were raided off the shores of Tabucan Baru (Kemmerling 1923: 6; Bataviaasch Nieuwsblad 1924). However, population pressure may have been one reason for decisions to return to settlements. Dutch volcanological researchers in the 1920s complained that the

\footnotetext{
$\overline{{ }^{6} \text { Baru and lama }}$ are Indonesian words and are now used on official maps but the Sangirese words for old and new, tebe and $b u h u$, are also used locally.
}

people of Tabucan, Kendahe and Tahuna had returned to the proximity of the lahar riverbeds in the years after the 1892 eruption (Kemmerling 1923: 11).

\section{Identity and Knowledge}

Communities remain mindful of Awu and the catastrophes it has caused, and both the physical features of the eruptions and the human experiences have been passed across generations. Names of villages and sites reinforce this risk awareness. For example, the 1711 eruption plays a central role in the political history of Kendahe, as it killed the king and his infant son and marked the beginning of a new dynasty (Widiyanto 2014: 2837; Seminar Sejarah 2017; Lopez 2018: 140). While the 1711 eruption is special because of its political legacy, historical records also indicate a longstanding tradition of retaining memories of previous eruptions. When a Dutch governor visited Sangihe in 1677, people spoke of a recent eruption that caused the top of Awu to collapse and that a lake had emerged in the crater causing concern that if the water rose, they were in danger of being engulfed by lahar flowing down the slopes during eruptions or earthquakes. They also informed the governor how, after the most recent eruption, livestock that grazed in the upland forest had been found burned but still standing. When touched, they immediately collapsed into a pile of ash, as they had been killed not by lahar or lava but a pyroclastic flow ('hot blast'). A similar event after the 1892 eruption had killed people in the church of Sawang, a village up the mountain from Tabucan. This anecdote was still being told 30 years later (Leupe 1867: 255-56; ANRI 1892; Kemmerling 1923: 29).

Eyewitness accounts of the eruptions of 1711, 1856, and 1892 show very clearly that people acted on experience-based knowledge. At least until the mid-twentieth century, the Sangirese used the word mekakoto to identify people whose task it was to monitor the crater. The word derives from the word kakoto, which means an offering (Van Delden 1844: 364; Leupe 1867: 254; ANRI 1892; Steller and Aebersold 1959). Apart from the more specific knowledge and experience passed across the generations, disaster risk, as in Mayon place names reflect memories of eruptions. For example, a number of village names include the word 'beha,' meaning 'rock from the crater.' Two areas, one north of Tabucan and one inland from Kendahe are called Sahabe, meaning 'scorched earth' (Steller and Aebersold 1959). Such spatial remembering was perhaps more generic than experiencebased information, but it would be a mistake to consider these ways of remembering separately. Rather they should be understood as complementary: during the eruption of 1711, the residents of Sahabe were reminded that they lived in a danger zone because the name of their settlement meant scorched earth. Previous experience passed on over time made villagers aware that they ran the risk of being engulfed by lahars. Faced 
with a similar situation in 1892, many of the inhabitants chose to flee (NA 1711: 183-193; ANRI 1892).

\section{Myths, Rituals, and Ceremonies}

Risk awareness is also expressed through myths, rituals, and ceremonies. As noted earlier, the centrality of Gunung Awu in the political and physical landscape of Sangihe is reflected in the fact that it was held to be the seat of the legendary warriorking, Maka-Ampo. The yearly Tulude festival in Kendahe includes an offering of food to the volcano to prevent bad luck. ${ }^{7}$ Oral traditions describe the dangers of the volcano, such as the tale of the giant Bakeng. During a struggle in which two brothers defended their sister against the giant and his wife who planned to eat the little girl, Bakeng fell into a crater. A recent version of the story tells how, after his fall, Bakeng's eyes were transformed into the lake. While he was falling, he shouted to the brothers that he would cause eruptions to chase them away so long as they and their descendants remained on the island. The brothers responded: 'When you become the volcano $[. .$.$] we will live on the eastern side to prevent this$ [destruction].' This version of the story not only explains why Awu erupts but also accounts for the persistence with which the people of Sangihe continue to live on the island and their readiness to move away during an eruption. Another version tells how the three siblings were turned into different wind directions. Winds affect pyroclastic falls and serve to warn people to be aware of the direction from which it blows when the volcano erupts (Adriani 1894: 41-55). ${ }^{8}$

Another story told particularly in Kendahe is that of the Kerajaan (palace) of Maselihe that, according to tradition, sank into the sea with all its treasures. People relate this story to the eruption of 1711 in which, as noted, the king and his son both died. Widiyanto (2014: 28-37) describes how people explain the disaster of 1711 in moral terms, and points particularly to the lasciviousness of members of the royal household. The eruption of 1711 is understood as a punishment for their immoral behaviour and endows the myth with explanatory power. Moreover, this morality is embedded in local belief in the spirit of Mawu, and, at the same time, resonates with Christian and Muslim prohibitions against sexual license (Christian et al. 2020). Interestingly, much of what might be considered mythical in this story is recorded in a Dutch diary by an eyewitness from Tabucan (NA 1711: 183-193). ${ }^{9}$ On the other hand, local informants in Kendahe tell how various groups of divers had tried unsuccessfully to find the remains

\footnotetext{
${ }^{7}$ Information provided by the inhabitants and village chief of Kendahe, January 2018.

${ }^{8}$ Two versions of the story of the giant Bankeng (Bio pa ansuang, areng-e I Bake) are reproduced and translated. For the most recent recorded version see Mangamba et al. (1995: 217-219).

${ }^{9}$ Francois Valentijn also records a copy (1726).
}

of Maselihe. Perhaps, in this instance, memory was conflated: the old palace may have been destroyed by lahars in 1711, but it was in 1856 that the area around Maselihe was badly hit and there was a major landslide where 'cliffs were formed where there had once been a beach' (ANRI 1856). Religion and morality continue to play an important role in the way people in Indonesia make sense of disaster and this enhances their resilience in times of duress (Samuels 2019: 1-28). Protestant missionaries claimed that the eruptions of 1856 and 1892 were an important factor in facilitating mass conversion among the island's population (Lopez 2018: 134-182). ${ }^{10}$

In 1923, the Dutch volcanological survey published a report on Awu. Its advice regarding disaster prevention was twofold: that the lake, at that time $150 \mathrm{~m}$ deep, was rising quickly, and that, based on measured volcanic activity, a disastrous eruption could be expected in the future. In the view of the survey team, strategies were needed to encourage people to migrate away from the volcano and settle in North Sulawesi. They advised that the aftermath of an eruption provided an opportunity to persuade people to migrate. By the time the eruption came in 1966, when the water in the lake was blown out of the crater, modern shipping enabled prompt evacuation and prevented a major disaster. In an operation that bore many similarities to the one proposed in 1923, over 27,000 people were transported by the Indonesian government to Poso and Manado on Sulawesi, where many were forced to remain. Still, the three original polities continue to exist as a basis of Indonesian administrative division, and the present day Kepala Kampong (headman) of Kendahe I, the village is split into two parts, traces his lineage back to the secretary of the king of Kendahe (ANRI 1856). ${ }^{11}$

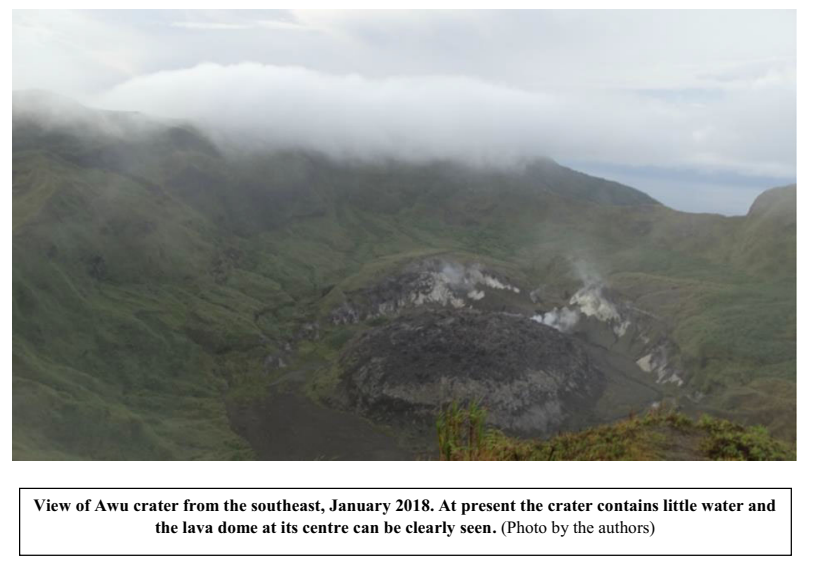

\footnotetext{
${ }^{10}$ Although Lopez does not attribute conversion to these disasters, the missionaries themselves did make the link (Valeton 1897: 1-55).

${ }^{11}$ This detailed file includes letters from Kendahe written by one of his ancestors during the period of disaster relief in 1856 .
} 


\section{Conclusion}

We make a case for the importance of social volcanology by drawing attention to the need to consider volcanoes using a mixed methodological approach that combines historical research, social science practice, and natural science insights. We compare the volcanoes of Mayon and Awu. Mayon has frequent small eruptions and relatively subtle or short eruption precursors, so VEI 4 eruptions are generally unanticipated. Awu erupts less frequently but exhibits stronger precursors and more VEI 4 eruptions. This might lead one to predict greater casualties at Mayon but the opposite is the case. Clearly, there are other factors at work here. We advocate a more historically sensitive approach that acknowledges the adaptations that people have made to living with volcanos in addition to one that merely seeks to calibrate the physical threat that they represent. The former constitutes what we call the centripetal force that draws people in towards the volcanic centre, and the latter constitutes the centrifugal forces that drive people away and that determines the level of risk.

Communities have historically settled around volcanoes, shifting location in response to disaster and/or creating new satellite settlements in places deemed to be more secure. At Mayon, the volcano's spatial geography created communities with distinctive cultural and linguistic identities that distinguished them from their neighbours. On Sangihe Besar, the settlement configuration around the volcano was centred on separate political identities, and where the manner and frequency of eruptions ensured a power balance between three polities. In both cases, adapting to the daily dictates imposed by the volcano became integrated into community culture and formed part of local identity. Risk awareness, too, is embedded in communities around Mayon and Awu in different ways but to similar ends. Past experiences are memorialised and communicated across generations with a remarkable sense of detail that both advertise geophysical threats and advocate risk avoidance behaviour. Place names serve as timely reminders of historical eruptions, while myths embody the community's past experiences (Vitaliano 1973). Names and myths not only remind people of the potential dangers they face but also help them make better sense of what life entails living within the 'charmed circle' of the volcano.

Often these forms of community adaptations are grouped together indiscriminately as instances of what is variously termed local, traditional, or indigenous knowledge. Stress is placed on integrating local views with scientific and expert knowledge both as a means of enlisting community participation through the coproduction of policies, and as a means of making disaster risk reduction more effective (Mercer et al. 2010; Gaillard and J. Mercer 2012). Indeed, indigenous knowledge has now been accorded 'official' status and been incorporated into policy and practice. In the four Priorities for Action agreed upon in the 2015 Sendai Framework for
Disaster Risk Reduction (DRR), the role of local communities in DRR is recognised alongside that of the state, and the importance of indigenous knowledge accepted in addition to scientific expertise (UNISRD 2015). An increasing number of case studies attest to the efficacy of such practices (Agrawal 1995; Sillitoe 1998; Berkes et al. 2000; Mercer et al. 2009; Lanzano 2013; Cronin et al. 2004). However, we argue that it is not just local knowledge that merits attention but also local history, which is the key to unlocking cultural memory in communities.

Only through exploring local history can the centripetal and centrifugal forces that a volcano generates be better understood and the cultural practices it fosters be taken fully into account in disaster risk mitigation planning and management. While the Albay Public Safety and Emergency Management Office (APSEMO) in the Philippines is considered a national leader in emergency planning, capacity building, and community mobilisation, and has a remarkable record in reducing losses in lives and property, it shows little awareness of local cultural considerations, at least, in its advocated practices (Gaerlan 2008). Nor does the history of Mayon feature in the local official school curriculum, although a few teachers take it upon themselves to organise class visits to the PHIVOLCS observatory located at the northeast slope of the volcano. ${ }^{12}$ On Sangihe island, the government's societal disaster risk reduction programme is largely confined to signposting evacuation routes around the volcano and the coast. The signposts are very visible reminders for the inhabitants of the risks they live with, yet some are critical of the language they use. For example, they express a preference for the local word for tsunami, luak dalulung. The use of English on signposts is at odds with local culture since it is not a common language for the islanders. At the time of our research, no use was made of local historical knowledge in risk awareness programmes in schools.

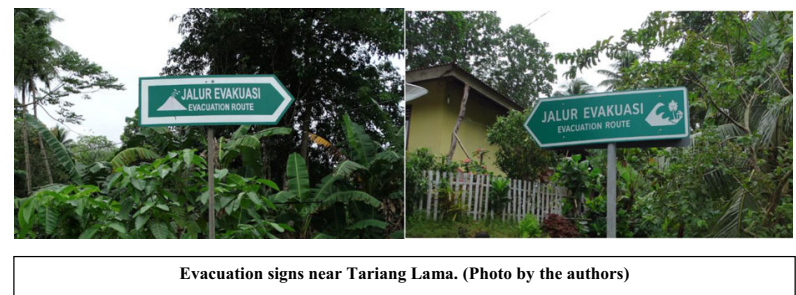

Social groups hold a consistent form of prioritising and explaining the misfortunes that assail them (Douglas and Wildavsky 1982). This collective experience is embedded in community traditions and customs that collectively constitute its local history and can take many forms, some passive (place names, legends, and memories), and others active (orally transmitted experiences, rituals, and processions). Together

\footnotetext{
${ }^{12}$ Private communication, resident of Santo Domingo, Albay, 13 January 2021.
} 
they dictate how a community reacts in times of danger. A better understanding of how history is embedded in local culture, why people do what they do and not just what they know, we hold, can facilitate dialogue across the social domains of knowledge that often separate those most exposed to risk from the physical scientists and civil defence personnel charged with reducing that exposure (Hilhorst 2004). The evacuation signposts on Sangihe Besar that point to safety in opposite directions remind us that there is more than one route to improving disaster risk reduction around volcanoes.

Authors' Contribution All authors contributed to the study conception and design. Material preparation, data collection and analysis were performed by Greg Bankoff, Chris Newhall and Alicia Schrikker. The first draft of each section of the manuscript was written by individual authors and all authors commented on previous versions of the manuscript. All authors read and approved the final manuscript.

Funding Funding for this research was provided by an Australian Research Council Linkage Grant No. LP150100649.

\section{Declarations}

Conflict of Interest The authors declare they have no conflict of interest.

Research Involving Human Participants and/or Animals All data were collected in compliance with ethical standards.

Informed Consent All interviews conducted with informed consent.

\section{References}

Aebersold W.E. (1957). "Bekem Makaampo / Het verhaal van Makaampo." BKI, 113, 2: 122-167.

Adriani, Nicolaus. 1894. Sangireesche Teksten. Met Vertaling En Aantekeningen. Den Haag: Nijhoff.

Agrawal, Arun. 1995. "Dismantling the Divide between Indigenous and Scientific Knowledge." Development and Change 26: 413-39.

ANRI. (1892). Reports and Correspondence on the Eruption of Gunung Awu 1892. Arsip Nasional Republik Indonesia Algemene Secretarie, Grote Bundel Besluit 1891-1942. Inv nr. 107.

ANRI. (1856). Stukken Omtrent de Uitbarsting van de Vuurberg op de Sangie Eilanden, 1856. Arsip Nasional Republik Indonesia Manado, $126 / 2$

AOM. (1814). La Erupción del Mayón en 1814 y el Traslado de Algunos Pueblos de la Iraya. Archives of the Manila Observatory Box 13, file 2/4.

Aragoneses, Francisco. 1815. Suceso Espantoso Acaecido en la Erupcion del Volcan de Albay en la Isla de Luzon, una de las Llamadas Filipinas. Madrid: Imprenta de Nuñez.

Bankoff, Greg. 2020. "Under the Volcano: Mount Mayon and CoVolcanic Societies in the Philippines." Environment and History 26 (1): 7-29.

Berkes, Fikret, Johan Colding, and Carl Folke. 2000. "Rediscovery of Traditional Ecological Knowledge As Adaptive Management." Traditional Ecological Knowledge 10: 1251-62

Bouvet de la Maisonneuve, Caroline, Lauriane Chardot, Fidel Costa, Susanna Jenkins, and Benoit Taisne. (2018). Eruption at Mayon
Volcano, Luzon Island, Philippines. Earth Observatory of Singapore News website, 19 January. Accessed January 27, 2021. https://earthobservatory.sg/news/eruption-mayon-volcano-luzonisland-philippines.

Christian, Yoppie, Desmiwati, and Ario Damar. 2020. "The Blessed Land: Internalisation of past Disaster into Culture by Sangihe's Coastal Community." International Journal Disaster Management 3 (1): $12-28$

Coronas, José. (1898). The Eruption of Mayon Volcano June 25, 26, Year 1897. Manila. Manuscript held by the Philippine Institute of Volcanology and Seismology Library, MO90.

Cronin, Shane J., David R. Gaylord, Douglas Charley, Brent V. Alloway, Sandrine Wallez, and Job W. Esau. 2004. "Participatory Methods of Incorporating Scientific with Traditional Knowledge for Volcanic Hazard Management on Ambae Island, Vanuatu." Bulletin of Volcanology 66: 652-68.:

Darenoh, Naroh. (2012). Tariang lombotari buhu/Sejarah Kamung Tariangbaru. Typescript, kept at Government Office Tariang Baru

van Delden, Arnoldus Johannes. (1844). De Sangir-eilanden in 1825. Indisch Magazijn 1 (4-6) 356-83 and 1 (7-9): 1-32

Donovan, Katherine. 2010. "Doing Social Volcanology: Exploring Volcanic Culture in Indonesia." Area 42 (1): 117-26.

Doocy, Shannon, Amy Daniels, Shayna Dooling, and Yuri Gorokhovich. 2013. The Human Impact of Volcanoes: A Historical Review of Events 1900-2009 and Systematic Literature Review. PLoS Currents 5 (16 April). https://doi.org/10.1371/currents.dis. 841859091a706efebf8a30f4ed7a1901:

Douglas, Mary and Aaron Wildavsky. 1982. Risk and Culture: An Essay on the Selection of Technological and Environmental Dangers. Berkeley: University of California Press.

Espinas, Merito B. c1996. Ibalong: The Bikol Folk Epic-Fragment: English and Bikol Translation, Views and Comments. Naga: University of Sto. Tomas Publishing House.

Gaerlan, Kristina. 2008. Building Resilient Communities: Good Practices in Disaster Risk Management in the Philippines. Quezon City: Oxfam.

Gaillard, Jean-Christophe and Jessica Mercer. 2012. "From Knowledge to Action: Bridging Gaps in Disaster Risk Reduction." Progress in Human Geography 37: 93-114.

Henley, David. 2005. Fertility, Food and Fever: Population, Economy and Environment in North and Central Sulawesi, 1600-1930. Leiden: KITLV press.

Hilhorst, Dorothea. 2004. "Complexity and Diversity: Unlocking Social Domains of Disaster Response". In Mapping Vulnerability: Disasters, Development and People, edited by Greg Bankoff, Georg Frerks and Dorothea Hilhorst, 52-66. London and Sterling: Earthscan.

Hoffman, Susanna M. and Antony Oliver-Smith. 1999. Anthropology and the Angry Earth: An Overview. In The Angry Earth: Disaster in Anthropological Perspectives, edited by Anthony Oliver-Smith and Susanna Hoffman, 1-16. New York and London: Routledge.

Jagor, Feodor. 1875. Travels in the Philippines. London: Chapman and Hall,

Kemmerling, Georg. L. 1923. De Vulkanen van de Sangi Archipel en van de Minahassa - Vulkan. Weltevreden: Landsdrukkerij.

Kutoyo, Sutrisno and Sigarlaki, A. 1982. Sejarah daerah Sulawesi Utara, Jakarta: Departemen Pendidikan dan Kebudayaan.

Lanzano, Cristiano. 2013. "What Kind of Knowledge Is 'Indigenous Knowledge'? Critical Insights from a Case Study in Burkina Faso." Transcience 4 (2): 3-18.

Leupe, Pieter Arend. 1867. "Het journaal van Padtbrugge's reis naar Noord Celebes en de Noordereilanden (16 aug-23 dec 1677)." BKI, 14: 105-340.

Lopez, Ariel. 2018. Conversion and colonialism. Islam and Christianity in North Sulawesi, c 1700 -1900. Unpublished Phd thesis, Leiden University. 
Local Historian. 2018. January 17. Interview, Camalig, Albay province, Philippines.

Local Resident. 2018. January 20. Interview, Santo Domingo Albay province, Philippines.

Mabbett, Ian W. 1983. "The Symbolism of Mount Meru." History of Religions 23 (1): 64-83.

Mallari, Francisco. 1986. "The Tragic Town in the Bicol Peninsula and the Failed Attempt to Transfer the Townsite before the Catastrophe of 1814." Kinaadman 8: 19-34.

Mangamba, Nelman, Pasaribu Christina and Maryott, Kenneth R. (1995). The origins of Awu volcano. Manga wěkeng asal u tau Sangihẹ: Cerita-cerita asal orang Sangir (Stories of the origins of the Sangir people). " Davao (Philippines): The Committee for the Promotion of the Sangir Language.

Mercer, Jessica, Ilan Kelman, Sandie Suchet-Pearson, and Kate Lloyd. 2009. "Integrating Indigenous and Scientific Knowledge Bases for Disaster Risk Reduction in Papua New Guinea." Geografiska Annaler: Series B, Human Geography 91: 245-56.

Mercer, Jessica, Ilan Kelman, Lorin Taranis, and Sandie Suchet-Pearson. 2010. "Framework for Integrating Indigenous and Scientific Knowledge for Disaster Risk Reduction." Disasters 34: 214-239.

NA. 1711. Extract Van HET Dagregister Gehouden Door den Resident AAN de Negorij Taboucan Sedert 10 tot 17 December 1711 en daar uijt Veroorsaakte Rampen. National Archives (The Hague) 1.04 .02 (VOC), 8081

Neall, Vince E. 2009. Volcanic Soils. In Land Use, Land Cover and Soil Sciences: Encyclopedia of Life Support Systems, edited by Willy H. Verheye, 23-45. Oxford: EOLSS Publishers Co Ltd.

Newhall, Christopher G. 1979. "Temporal Variation in the Lavas of Mayon Volcano, Philippines." Journal of Volcanology and Geothermal Research 6 (1-2): 61-83.

Newhall, Christopher G. and Raymundo S. Punongbayan, eds. 1996. Fire and Mud: Eruptions and Lahars of Mount Pinatubo, Philippines. Seattle: University of Washington Press.

Newhall, Christopher G., Sarah E. Albano, Norio Matsumoto, and Teodorico Sandoval. 2001. "Roles of Groundwater in Volcanic Unrest." Journal of the Geological Society of the Philippines 56 (3\&4): 69-84.

O'Brien, James J. 1968. Historical and Cultural Heritage of the Bicol People. Naga City: Ateneo de Naga.

PVMBG (Pusat Vulkanologi dan Mitigasi Bencana Geologi). 2011. Data Dasar Gunung Api Indonesia. Vol 2. Kementerian Energi dan Sumber Daya Mineral. Second edition.

Redford, Robert. 1956. Peasant Society and Culture: An Anthropological Approach to Civilisation. Chicago: University of Chicago Press.

Riedel, Joh. Gerard Fried. 1867. De uitbarsting van de Awoeh-Taruna in 1856. Tijdschrift voor Indische Taal Land en Volkenkunde, 11: 9196.

Samuels, Annemarie. 2019. After the Tsunami. Disaster Narratives and the Remaking of Everyday Life in Aceh. Honolulu: University of Hawaii Press.

Seminar Sejarah: Kendahe i'kekendage (2017) (A report of a seminar on the history of Kendahe). Printed copy was obtained at the government office in Kendahe.
Schlehe, Judith. 1996. "Reinterpretations of Mystical Traditions: Explanations of a Volcanic Eruption in Java." Anthropos 91: 391409.

Schrikker, Alicia. (2016). Disaster management and colonialism in the Indonesian archipelago, 1840-1920. Bankoff, Greg and Christensen, Joseph (EDS). Natural Hazards and Peoples in the Indian Ocean World. Bordering on danger. New York: Palgrave Macmillan. 225254

Shinoara, Hiroshi, Keiichi Fukui, Kohei Kazahaya, and Genji Saito. 2003. "Degassing Process of Miyakejima Volcano: Implications of Gas Emission Rate and Melt Inclusion Data." Developments in Volcanology 5: 147-61.

Small, Christopher and Terry Naumann. 2001. "Holocene Volcanism and the Global Distribution of Human Population." Environmental Hazards 3 (3/4): 93-109.

Sillitoe, Paul. 1998. "The Development of Indigenous Knowledge: a New Applied Anthropology." Current Anthropology 39: 223-52.

Steller K.G.F. and. Aebersold W.E 1959. Sangirees-Nederlands woordenboek. The Hague: Nijhoff.

Surono, Philippe Jousset, John Pallister, MarieBoichud, M. Fabrizia Buongiorno, Agus Budisantoso, Fidel Costa, Supriyati Andreastuti, Fred Prata, David Schneider, Lieven Clarisse, Hanik Humaida, Sri Sumarti, Christian Bignami, Julie Griswold, Simon Carn Clive Oppenheimer, and Franck Lavigneo. 2012. "The 2010 Explosive Eruption of Java's Merapi Volcano - A '100 Year' Event." Journal of Volcanology and Geothermal Research 241242 (1): 121-35.

Tambiah, Stanley J. 2013. The Galactic Polity in Southeast Asia. Journal of Ethnographic Theory 3 (3): 503-534. First published 1973.

UNISDR (United Nations International Strategy for Disaster Reduction). 2015. Sendai Framework for Disaster Risk Reduction 2015-2030. Accessed January 28, 2021. http://www.wcdrr.org/uploads/Sendai Framework_for_Disaster_Risk_Reduction_2015-2030.pdf.

Valentijn, François. 1726 Oud en Nieuw Oost-Indien [...]. Dordrecht/ Amsterdam: Joannes van Braam.

Valeton, Josué Jean Philippe 1897. "Ernst Traugott Steller.” Lichtsralen op den akker der wereld 3

Vitaliano, Dorothy B. 1973 Legends of the Earth: Their Geological Origins. Bloomington: Indiana University Press.

Warren, James F. 1981. The Sulu Zone, 1768-1898: The Dynamics of External Trade, Slavery, and Ethnicity in the Transformation of a Southeast Asian Maritime State. Singapore: Singapore University Press.

Whelley, Patrick L., Christopher G. Newhall, and Kyle E. Bradley. 2015. "The Frequency of Explosive Volcanic Eruptions in Southeast Asia." Bulletin of Volcanology 77 (1): 1-11.

Widiyanto, Nur. 2014. "The challenges of myth-based coexistence between Christians and Muslims in Kendahe, Sangihe island, North Sulawesi province." Jurnal Etnohistori, 1: 28-37.

Zeeroof bij de Sangi-eilanden. Bataviaasch Nieuwblad, 4 September 1924.

Publisher's Note Springer Nature remains neutral with regard to jurisdictional claims in published maps and institutional affiliations. 